\title{
Kinerja Aspek Sosial dalam Pengelolaan Hutan Alam Lestari: Studi Kasus pada HPH PT. Sumalindo Lestari Jaya (SLJ) II Provinsi Kalimantan Timur
}

Pudji Muljono

\begin{abstract}
Social aspect is one of important aspects to be considered in the analysis of sustainable forest management performance. This article discusses the analysis of social aspect of sustainable forest management as taking place at one of production unit of PT (SLJ) II in East Kalimantan. Ten indicators were employed to help elaborate sustainable forest management performance in this study. These indicators were considered to represent keys social aspect influencing the management performance at that unit of production. The employed indicators are to comply with sustainable forest management certification system as formulated by Lembaga Ekolabel Indonesia 2000. Based on the analysis, it is indicated that PT SLJ II accomplished good enough social performance in running sustainable forest management. However, it is also shown that the implementation of good social aspect performance did not help the company to improve the level of community welfare status yet. The finding of the study is expected to give an enrichment matter to the process of how sustainable forest management should be operated and be achieved in the field.
\end{abstract}

Keywords: social aspect performance, sustainable forest management

\section{PENDAHULUAN \\ Latar Belakang}

Sejak tahun 1992 PT Sumalindo Lestari Jaya (PT SLJ) II telah melaksanakan kegiatan Pembinaan Masyarakat Desa Hutan (PMDH) pada desa-desa di sekitar perusahaan. Studi diagnostik dengan menggunakan metode PRA (Participatory Rural Appraisal) telah dilakukan pada tahun 1993 kemudian direvisi pada tahun 2002. Adanya revisi studi diagnostik tersebut dikarenakan adanya perubahan desa binaan. Sampai tahun 1999, desa binaan PT SLJ II meliputi Desa Batu Majang dan Long Bagun Tengah di Kecamatan Long Bagun Kabupaten Kutai Barat serta Desa Mahak Baru, Dumu Mahak, Lebusan dan Long Top di Kecamatan Sungai Boh Kabupaten Malinau.

Sejak tahun 2000, kegiatan pembinaan masyarakat oleh PT SLJ II lebih difokuskan pada desa-desa di Kecamatan Sungai Boh Kabupaten Malinau yang meliputi Desa Mahak Baru, Dumu Mahak, Lebusan, Long Top dan Agung Baru. Hal ini dikarenakan semakin dekatnya akses ke desa-desa tersebut dan adanya dampak langsung dari kegiatan operasional perusahaan terhadap desa-desa tersebut. Sedangkan terhadap desa-desa yang berada di kecamatan Long Bagun Kabupaten Kutai Barat, dengan alasan kedekatan lokasi dan pengaruh dampak pengelolaan, 
kegiatan PMDH diserahterimakan kepada unit perusahaan baru yaitu PT Sumalindo Lestari Jaya V (tahun 2000).

Dalam pelaksanaan kegiatan PMDH, selain aspek fisik pembangunan desa juga diarahkan pada pengelolaan konservasi atau perlindungan ekosistem secara partisipatif dengan warga desa. Dengan melibatkan partisipasi masyarakat maka kegiatan perlindungan hutan dan ekosistemnya menjadi lebih fokus dan tepat sasaran. Metode yang digunakan adalah metode PCP (Participatory Concervation Planning). Dengan metode PCP ini, proses konsultasi secara partisipatif dengan masyarakat dapat mengidentifikasi sumberdaya alam penting, menilai kondisinya, perubahan atau penurunan keberadaan serta daya tahan sumberdaya alam (SDA), indikator perubahan, sumber-sumber yang menyebabkan penurunan SDA, strategi untuk mempertahankan SDA dengan mengurangi aktivitas penyebab perubahan kondisi SDA, serta para pihak yang terlibat dalam semua tahapan. Dari proses konsultasi tersebut akan diperoleh beberapa indikator keberhasilan yang dapat diukur dan dimonitor. Semua hal tersebut penting untuk mengetahui apakah areal ini memiliki nilai konservasi tinggi dan strategi apa yang dibutuhkan untuk perencanaan kawasan agar ada jaminan nilai-nilai tersebut tidak hilang atau terdegradasi bahkan semakin membaik.

Dengan metode PCP yang telah dilakukan, PT SLJ II telah melakukan kegiatan penataan batas partisipatif terhadap wilayah desa, tanah adat/ulen serta wilayahwilayah adat desa lainnya. Identifikasi hak-hak adat telah dilakukan oleh PT SLJ II melalui komunikasi dengan pihak masyarakat secara aktif dan timbal balik. Sehingga lokasi tanah ulen sebagai sumber kebutuhan masyarakat sehari-hari, kawasan tegakan ulin, sarang burung dan situs-situs sejarah adat dapat dilindungi. Hak-hak adat tersebut telah diakui oleh PT SLJI II dengan telah dilakukannya pengukuran pertisipatif secara definitif di lapangan pada semua desa yang ada dalam areal kerja (lima desa yaitu Desa Mahak Baru, Dumu Mahak, Long Lebusan, Long Top dan Long Agung Baru). Dari total luas kawasan sosial 14854.67 ha sebanyak $82.82 \%$ sudah ditatabatas partisipatif di lapangan.

Secara lengkap kawasan sosial yang telah diidentifikasi oleh PT SLJ II adalah sebagai berikut:

1. Desa Mahak (Dumu Mahak dan Mahak Baru).

- $\quad$ Batas ladang dan gilir balik atau wilayah desa seluas 3602,36 ha sudah ditatabatas partisipatif tahun 2001.

- Tanah ulen untuk Desa Mahak Baru dan Dumu Mahak telah ditetapkan lokasinya dan saat ini sedang dalam proses tatabatas, hal ini terkait dengan RKT 2010 dan seterusnya.

- $\quad$ Lokasi hasil hutan non kayu (HHNK) berupa tegakan ulin seluas 226.58 ha (tahun 2001) dan rotan seluas 881,70 ha (tahun 2003) sudah ditatabatas.

2. Desa Long Lebusan

- $\quad$ Batas ladang dan gilir balik atau wilayah desa seluas 3073,41 ha sudah ditatabatas partisipatif tahun 2002.

- Tanah ulen sudah ditatabatas partisipatif seluas 742.75 ha pada tahun 2003. 


\section{Desa Long Top}

- $\quad$ Batas ladang dan gilir balik atau wilayah desa seluas 242.06 ha sudah ditatabatas partisipatif tahun 2004.

- Tanah adat Desa Long Top berada di luar area konsesi unit manajemen, pada tahun 2008 ini desa ini akan pindah ke Muara Sungai Uhu.

4. Desa Agung Baru

- $\quad$ Batas ladang dan gilir balik atau wilayah desa seluas 2479.65 ha sudah ditatabatas partisipatif tahun 2005.

- $\quad$ Lokasi tanah ulen sudah ditetapkan dimana hal ini terkait RKT 2009.

Sedangkan untuk buffer perluasan desa dan ladang di Kecamatan Sungai Boh (termasuk desa Sungai Barang di Long Nawang) dicadangkan 2.551,75 ha. Desadesa tersebut berada di ujung utara dari areal PT SLJ II, dan prediksi interaksi kelola sosial sekitar mulai tahun 2016 atau RKL VII.

Dalam dokumen unit manajemen tentang konsep pengelolaan aspek sosial tahun 2006 dinyatakan bahwa berdasarkan hasil kegiatan studi diagnostik dengan menggunakan metode PRA dan PCP, PT SLJ II telah membuat program-program pemberdayaan masyarakat yang bersifat bantuan dalam bentuk program donasi sosial dengan tujuan untuk mendidik masyarakat hidup mandiri, di antaranya :

a. Bantuan BBM untuk setiap desa memperoleh 200 liter per bulan sehingga masyarakat desa dapat menikmati listrik desa.

b. Bantuan beasiswa anak sekolah dari tingkat SD hingga perguruan tinggi, buku paket, sarana olah raga dan honor guru.

c. Bantuan transportasi dua unit dumptruck untuk keperluan belanja ke Kecamatan Long Bagun di Kabupaten Kutai Barat (164 Km pulang pergi) setiap dua minggu sekali. Dengan adanya kemudahan ini maka harga-harga barang pokok dan lainnya menjadi turun hingga 50\% dibanding sebelum adanya jalan tembus dan bantuan transportasi tersebut.

d. Bantuan penyuluhan pertanian, peternakan, kebun sayur mayur dan budidaya gaharu. Khusus hasil sayur mayur pihak perusahaan membeli hasil sayur tersebut melalui koperasi.

e. Bantuan pelatihan mekanik, elektrik dan teknisi komputer.

f. Bantuan tenaga paramedis dan pengobatan gratis.

g. Bantuan pembangunan fisik desa, seperti perluasan/penggusuran lahan untuk pembangunan desa/kecamatan, renovasi tempat ibadah, balai adat/lamin (balai pertemuan umum).

h. Bantuan pembuatan jalan dari Km 146 sampai 149, pembangunan jembatan dan parit serta bantuan pemeliharaan jalan sampai dengan Km 164, jembatan dan parit desa. 


\section{Tujuan Studi}

Secara umum studi ini bertujuan untuk menganalisis bagaimana kinerja aspek sosial dalam rangka pengelolaan hutan alam lestari pada HPH PT SLJ II di Provinsi Kalimantan Timur. Adapun tujuan khusus dari studi ini adalah :

a. Mendeskripsikan dan mengkaji kinerja aspek sosial pada pengelolaan hutan alam lestari yang dikelola oleh PT SLJ II di Provinsi Kalimantan Timur;

b. Mengkaji berbagai upaya yang telah dilakukan dalam pembinaan masyarakat desa sekitar hutan yang dilakukan oleh PT SLJ II di Provinsi Kalimantan Timur.

\section{Metode Pelaksanaan}

Studi ini dilakukan melalui pengamatan langsung pada unit manajemen PT SLJ II terutama pada objek atau lokasi yang terkait dengan pembinaan masyarakat desa hutan dan kinerja aspek sosial pengelolaan hutan alam lestari. Kelengkapan data juga didukung dengan data dokumen, serta wawancara mendalam terhadap informan dan responden terkait. Proses pengumpulan data dilakukan dengan mengacu pada pedoman sertifikasi pengelolaan hutan lestari yang diterbitkan oleh Lembaga Ekolabel Indonesia tahun 2000. Pengamatan dilakukan khususnya terhadap indikator-indikator penting yang berpengaruh terhadap kinerja aspek sosial pada unit manajemen. Pengumpulan data dilaksanakan pada bulan Juni 2008. Data yang terkumpul selanjutnya dianalisis secara deskriptif dan sistematis.

\section{GAMBARAN UMUM}

\section{Keadaan Penduduk Sekitar Kawasan}

Pada awal kegiatan PT SLJ II beroperasi di sekitar Long Bagun yang merupakan Daerah Aliran Sungai Mahakam. Di wilayah Long Bagun, sebagian penduduknya adalah orang Dayak Penihing dan Bakumpay yang tinggal di desa-desa Long Bagun Ilir, Long Bagun Hulu, Batu Kelau, Batu Majang, dan Ujoh Bilang. Areal kerja unit manajemen PT SLJ II kemudian naik ke utara menuju hulu, dan pada tahun 19981999 mulai berinteraksi dengan penduduk desa-desa Dumu Mahak, Mahak Baru, Long Lebusan dan Long Top. Dalam beberapa tahun terakhir ini, bertambah satu desa baru lagi di sekitar empat desa tersebut, yaitu desa Agung Baru, yang merupakan migrasi dari 100-an keluarga dari Sungai Barang. Desa-desa di sebelah selatan konsesi berada dalam satuan administrasi Kutai Barat; sementara di Utara konsesi masuk ke dalam wilayah Kabupaten Bulungan.

Orang desa Mahak (terdiri dari dua desa: Dumu Mahak dan Mahak Baru yang wilayahnya bersebelahan, seringkali disebut Mahak saja dan dalam kegiatan unit manajemen biasanya disatukan programnya), Long Lebusan dan Agung Baru adalah Orang Kenyah yang masih bertalian kerabat dengan orang Apo Kayan di hulu sungai Kabupaten Malinau. Sementara desa Longtop didiami oleh kelompok orang Punan yang menetap dan berladang di sekitar sungai Ogap. Mereka menetap di sekitar sungai Ogap di perbatasan PT SLJ II dengan HPH PT Ranggakesuma karena ada jalan koridor untuk mengangkut kayu log turun ke Mahakam. Setelah PT Ranggakesuma tutup dan jalan itu tidak terpelihara, orang Punan di Long Top mulai berkelana lagi. 
Secara fisik desa Dumu Mahak, Mahak Baru, Long Lebusan, Long Top dan Sungai Agung Baru sangat terisolir. Sarana transportasi hanya berupa pesawat terbang dimana lokasi pendaratannya ada di Mahak dan Long Lebusan. Pesawat rute Samarinda ke Mahak dan Long Lebusan dioperasikan oleh misi nasrani sejak tahun 1980-an. Untuk mencapai kedua desa ada dua jalur; dari arah utara melalui Long Nawan, bisa dicapai dengan berjalan kaki selama 6 jam. Sementara dari selatan, yaitu Long Bagun, waktu tempuhnya adalah 3 hari dengan perahu dan jalan kaki; perahu tidak bisa menembus sampai desa dan hanya sampai sungai Boh saja karena banyak riam dan air terjun. Setelah perusahaan PT SLJ II membuka kegiatan dan membangun camp di km 122, jarak tempuh ke Mahak berkurang menjadi 8 jam dari ujung jalan HPH PT SLJ II ditambah 2 jam perjalanan dengan menumpang truk HPH PT SLJ II ke camp. Dari camp km 122, dengan menumpang truk HPH PT SLJ II, Long Bagun bisa dicapai dalam 2 jam.

Penduduk desa-desa tersebut masih sangat tergantung pada hutan dan perladangan padi lahan kering sebagai mata pencaharian sehari-hari. Penghuni pertama di desa Mahak adalah migran dari desa-desa Apokayan yang di lokasi asalnya sudah terlalu padat dan wilayah ladangnya makin sempit. Mereka lalu berpindah, sekitar akhir 1960 sampai awal 1970-an, dan membuat desa baru di tepian sungai Mahak. Di lokasi baru ini mereka meneruskan kebiasan berladang padi dan meramu hasil hutan. Jenis-jenis hasil hutan yang mereka manfaatkan terutama adalah gaharu, sayuran, buah-buahan, madu, rotan dan sarang burung. Hewan buruan yang diburu terutama adalah babi hutan dan rusa untuk dimakan, serta landak dan monyet untuk diambil batu geliganya. Selain itu mereka juga memancing ikan di sungai. Perburuan dilakukan di wilayah hutan adat yang bernama tanah ulen. Hutan adat ini juga dipakai sebagai lokasi cadangan untuk perladangan dan lokasi pengambilan kayu bagi kepentingan masyarakat.

Saat ini, penduduk desa Mahak mendiami areal desa dan wilayah perladangan yang masih cukup luas. Setelah melalui pemetaan partisipatif di Mahak dan Long Lebusan, diketahui bahwa luas ketiga desa tersebut adalah 3.021 ha (Mahak Baru dan Dumu Mahak) dan 3.654 ha (Long Lebusan). Dengan luasan dan jumlah penduduk demikian, maka kepadatan penduduk di desa-desa itu terlihat masih jarang dan untuk berladang-pindah sekalipun nampaknya masih cukup ada tempatnya.

Berdasarkan Laporan Hasil Survey Sosial Ekonomi dan Budaya di Desa Binaan PT SLJ II tahun 2007 diketahui bahwa jumlah kepala keluarga di desa binaan tersebut adalah Desa Mahak Baru 156 KK, Desa Dumu Mahak 98 KK, Desa Long Lebusan 122 KK, Desa Long Top 11 KK, Desa Agung Baru 54 KK, dan Desa Data Baru 44 KK.

\section{Program Kelola Sosial}

Rencana Pengelolaan Sosial PT SLJ II dilakukan dengan memperhatikan kondisi sosial ekonomi desa-desa binaan yang ada di dalam areal kerja. Semua desa binaan (Dumu Mahak, Mahak Baru, Long Lebusan, Long Top dan Agung Baru) berada dalam wilayah areal kerja PT SLJ II di Kecamatan Sungai Boh Kabupaten Malinau. Selain itu terdapat satu desa di sebelah utara yang aksesnya masih sangat sulit, yaitu desa Sungai Barang di Long Nawang. Transportasi ke sana hanya dapat ditempuh 
dengan jalan kaki selama seminggu dari desa Mahak atau naik pesawat perintis. Operasional logging akan mendekati desa tersebut sekitar tahun 2016 atau RKL VII.

Arah dari kelola sosial adalah terjadinya minimasi konflik dengan masyarakat baik konflik pemanfaatan hasil hutan maupun konflik kawasan hutan, serta mendorong terciptanya kondisi pembentukan masyarakat yang mandiri dalam membangun wilayah desanya. Dengan demikian pengelolaan kelola sosial yang lestari akan mendukung kelestarian fungsi ekologi dan produksi dari pemanfaatan hutan.

Peraturan Menteri Kehutanan No. P.11/Menhut-II/2004 tanggal 29 September 2004 tentang pencabutan SK Menteri Kehutanan No. 523/KPTS-II/1997 tentang Pembinaan Masyarakat Desa Hutan oleh pemegang HPH dan HPHTI, dan SK Menteri Kehutanan No. 165/KPTS-II/1998 tentang biaya satuan PMDH bagi pemegang HPH menyebutkan bahwa penyelenggaraan pembinaan masyarakat desa hutan oleh pemegang ijin usaha pada hutan alam dan pemegang ijin usaha pada HTI menjadi satu kesatuan di dalam pengelolaan hutan secara lestari sesuai SK Menteri Kehutanan tanggal 3 Juni 2002 No. 4795/Kpts-II/2002 (untuk hutan alam) dan No. 177/Kpts-II/2003 tanggal 12 Juni 2003 (untuk HTI).

Menyikapi kondisi "adanya potensi rawan sosial" dalam menangani kelola sosial, maka strategi yang diterapkan oleh PT SLJ II terbagi menjadi:

a. Melaksanakan program kegiatan yang bersifat peningkatan perekonomian, dan bantuan sarana dan prasarana sosial (pendidikan, kesehatan, keagamaan dan sosial lainnya). Kegiatan dilakukan secara bertahap sesuai tatanan waktu yang ada.

b. Melaksanakan program kegiatan konservasi sumber daya hutan, termasuk didalamnya perlindungan tanah adat/ulen, lokasi hasil hutan non kayu, sumber air/sungai utama sebagai kebutuhan dasar masyarakat, dan kegiatan perladangan. Program kegiatan ini dilaksanakan secara partisipatif dengan masyarakat secara berkesinambungan.

Berkaitan dengan pengelolaan sosial dalam aspek konservasi, PT SLJ II bersama masyarakat telah mengidentifikasi sumber-sumber daya alam yang sangat penting bagi masyarakat dengan menggunakan metode Participatory Concervation Planning (PCP). Hasilnya diketahui sumberdaya alam yang penting bagi masyarakat desa, prediksi kecenderungan kondisi sumberdaya alam dimasa yang akan datang, sumber ancaman terhadap sumberdaya alam penting tersebut dan strategi yang ingin diterapkan. Hal tersebut menjadi dasar bagi kegiatan pengelolaan sosial khususnya dan pengelolaan hutan umumnya oleh PT SLJ II. Secara lengkap rencana strategi pengelolaan konservasi dan ancaman terhadap SDA dapat dilihat dalam table-tabel berikut. Berdasarkan kondisi tersebut maka rencana kegiatan pengelolaan sosial disusun, dengan berdasarkan SK Menhut No 4795/Kpts-II/2002 tanggal 3 Juni 2002.

Sehubungan dengan itu UM PT SLJ II juga telah mengadakan Studi Program Pembangunan Desa di Kecamatan Sungai Boh dengan Metode Participatory Rural Appraisal PT SLJ II pada tanggal 10-11 September 2006 (Desa Lebusan), 11 September 2006 (desa Data Baru/persiapan), 12 September 2006 (desa Agung Baru), 13-14 September 2006 (Desa Dumu Mahak dan Mahak Baru). Maksud dilaksanakannya kegiatan itu adalah untuk memfasilitasi masyarakat desa binaan dalam mengevaluasi program pembangunan dan penyusunan rencana pembangunan 
jangka menengah desa (periode 2007-2011) dan sebagai acuan UM dalam penyusunan rencana kerja lima tahunan pembinaan masyarakat desa (RKL PMDH).

PT SLJ II sebagai perusahaan industri perkayuan terpadu dalam mengelola usahanya sejak awal senantiasa berusaha untuk mewujudkan perusahaan yang bermanfaat dan dapat diterima serta memperoleh dukungan dari seluruh stakeholders, baik itu pemerintah, masyarakat maupun pengguna produk (community friendly company). Sejalan dengan perkembangan dan peningkatan perhatian perusahaan di bidang community development, maka untuk lebih fokus dalam mewujudkannya, unit manajemen menetapkan langkah-langkah kebijakan sebagai berikut:

a. Tetap berkesinambungan untuk membuka kesempatan kerja dengan melibatkan peran serta masyarakat sejalan fungsi keberadaan perusahaan yaitu dapat meningkatkan kesejahteraan masyarakat sekitar usaha.

b. Terus berusaha membentuk satuan-satuan usaha kemitraan yang saling menguntungkan antara perusahaan dan masyarakat sekitar seiring dengan program pemerintah.

c. Terus berupaya menjaga situasi yang kondusif di sekitar lokasi kerja untuk menciptakan ketenangan bekerja dan keserasian hubungan antara perusahaan dengan masyarakat.

d. Dalam menjalankan operasional harus berpegang kepada aturan-aturan yang ditetapkan oleh pemerintah maupun badan-badan sertifikasi di bidang lingkungan.

\section{Ketenagakerjaan}

Pekerja di unit manajemen PT SLJ II digolongkan ke dalam dua kategori besar yaitu pegawai JWT (jangka waktu tertentu atau pekerja tidak tetap) dan pegawai JWTT (jangka waktu tidak tertentu atau pekerja tetap). Setiap pegawai JWTT terikat dalam perjanjian kerja bersama (PKB) yang disetujui oleh perwakilan mereka di serikat pekerja. Hak dan kewajiban pegawai diatur dalam PKB yang meliputi: hubungan kerja, waktu kerja, kewajiban pekerja, pengupahan, fasilitas kesehatan, jaminan sosial, training, insentif, keselamatan kerja, sanksi, mekanisme penyelesaian sengketa buruh dan aturan pemutusan hubungan kerja. Untuk karyawan JWTT kontrak kerja merujuk langsung ke PKB, sementara karyawan JWT menyesuaikan dengan aturan di PKB. Penyesuaian itu berkaitan dengan pengupahan dan fasilitas yang diberikan perusahaan. PKB diturunkan dalam kontrak kerja yang merupakan perjanjian antara manajemen dengan karyawan. Perusahaan telah memiliki dan mensosialisasikan Perjanjian Kerja Bersama periode tahun 2007-2009 yang berakhir pada tanggal 28 Maret 2009. Selanjutnya berdasarkan Surat Keputusan Kepala Dinas Tenaga Kerja dan Transmigrasi Propinsi Kalimantan Timur No. KEP.075/207/BHI/DTKT tanggal 24 April 2007 tentang Pendaftaran Perjanjian Kerja Bersama (PKB) antara PT SLJ Tbk dengan Serikat Pekerja/Serikat Buruh PT SLJ Tbk telah ditetapkan bahwa PKB perpanjangan berlaku mulai tanggal 27 Maret 2007 sampai dengan tanggal 28 Maret 2009.

Tingkat kesejahteraan karyawan UM PT SLJ II nampaknya dianggap sudah memadai oleh karyawan. Salah satu buktinya adalah tingkat keluar/DO yang rendah 
di perusahaan dan banyaknya pegawai dengan masa kerja di atas 10 tahun. Peninjauan gaji secara berkala diprogramkan dan sudah ada SOP untuk melaksanakannya. Gaji terendah masih di atas UMR yang sekarang ini untuk sektor kehutanan di Kalimantan Timur. Berdasarkan SK. Gubernur Kalimantan Timur No. 561/K.532/2006 tanggal 14 Desember 2006 tentang Penetapan Upah Minimum Sektoral Provinsi (UMSP) Sektor Perkayuan dan Kehutanan Kalimantan Timur Tahun 2007, ditetapkan besarnya UMSP Sektor Perkayuan dan Kehutanan sebesar Rp. 804.825,-. Keputusan ini berlaku sejak tanggal 1 Januari 2007 sampai tanggal 31 Desember 2007. Sebagai upaya untuk mematuhi ketentuan tersebut, pihak unit manajemen telah mengeluarkan SK Keputusan Direksi tentang penyesuaian Perubahan Upah tersebut. Berdasarkan hasil keterangan unit manajemen, setelah keluarnya surat keputusan baru untuk tahun 2008 maka direksi akan segera menerapkan ketentuan itu dan berlaku surut per 1 Januari 2008.

Program peningkatan karir didukung dengan berbagai training yang terprogram, yang pelaksanaannya dilakukan oleh bagian training perusahaan (Training CenterSumalindo Group) atau dengan mengirimkan karyawan ke instansi di luar perusahaan. Fasilitas fisik karyawan di kamp memadai, baik untuk karyawan yang datang sendiri maupun dengan keluarga. Fasilitas sekolah, mulai dari TK sampai SMP tersedia di sekitar kamp. Unit manajemen membangun TK di camp dan membantu kelancaran pendidikan di SD, SMP dan SMA antara lain dengan bantuan kapal pengangkut murid sekolah di $\mathrm{km} 0$. Fasilitas kesehatan juga dilengkapi dengan tenaga medik mulai dari dokter sampai mantri. Di ketiga camp yang ada, ketiganya dilengkapi dengan poliklinik.

Penyerapan tenaga kerja lokal cukup tinggi, walaupun sebagian berada dalam posisi pegawai kontrak atau borongan. Tenaga kerja dari luar Kalimantan, seperti dari NTT juga ada dalam jumlah puluhan. Salah satu hal yang mesti diperdalam lagi adalah kesempatan karir pada tenaga kerja lokal dalam manajemen PT SLJ II dan program pelatihan yang dirancang untuk meningkatkan kapasitas mereka. Pemenuhan tenaga kerja yang dilakukan oleh PT SLJ II didasarkan pada beberapa kriteria di antaranya adalah: mengacu pada standard Tenaga Teknis Kehutanan Indonesia, berdasarkan kebutuhan organisasi dan mementingkan penggunaan tenaga kerja lokal dibandingkan dari luar daerah.

\section{KINERJA ASPEK SOSIAL}

\section{Akses dan kontrol masyarakat terhadap kawasan hutan adat Klaim terhadap kawasan wilayah masyarakat}

PT SLJ II bersama-sama masyarakat lima desa di dalam kawasan hutan telah menyelesaikan pemetaan partisipatif pada seluruh areal desa dan areal adat yang berada di dalam areal SLJ II pada tahun 2004. Pada Agustus 2006 Departemen Kehutanan mengesahkan Rencana Kerja Usaha Pemanfaatan Hasil Hutan Kayu (RKUPHHK) PT. SLJ II untuk jangka waktu pengelolaan 2006-2051. Di dalam dokumen RKUPHHK tersebut juga menunjukkan keberadaan hutan adat (tanah ulen) dan tanah desa di dalam areal PT SLJ II dan mengeluarkannya dari areal efektif UMH.

Pada bulan September 2006 unit manajemen melaksanakan sosialisasi kembali mengenai kawasan hutan adat dan tanah desa setelah RKUPHHK disahkan oleh pemerintah pusat (Departemen Kehutanan). Bersamaan dengan itu areal kawasan 
hutan adat dan tanah desa diakui dan dikukuhkan keberadaannya oleh masyarakat adat (yang diwakili kepala adat) dan pemerintahan desa dan kecamatan. Sejak saat itu kepala adat besar, kepala desa dari kelima desa dan camat seperti halnya unit manajemen PT SLJ II masing-masing memiliki satu copy peta tersebut di atas. Semua kawasan komunitas masyarakat adat yang berada dalam kawasan konsesi telah dikeluarkan dari areal efektif untuk produksi.

Pada saat kegiatan dilakukan pengamatan, tidak dijumpai kasus sengketa tenurial dalam kawasan konsesi unit manajemen PT SLJ II. Informasi mengenai situasi desa yang tercantum pada peta untuk Desa Agung Baru dan Desa Long Top hanya menggambarkan lokasi perladangan dan desa. Berbeda dengan peta partisipatif yang dibuat untuk desa-desa sebelumnya, dimana peta tersebut mencantumkan beberapa informasi seperti tanah ulen, lokasi pemukiman, sarana ibadah, sarana pendidikan dan infrastruktur lainnya. Menurut staf perusahaan, adanya perbedaan ini dikarenakan untuk kedua desa tersebut masih akan terjadi pengembangan pemukiman (belum settle), sehingga kemungkinan dapat berubah. Mengingat lokasi tanah ulen untuk Desa Long Top dan Desa Agung Baru berada di luar areal kawasan konsesi, maka informasi tanah ulen pada kedua peta tersebut tidak tergambarkan. Selanjutnya dalam dokumen Rencana Kerja Usaha Pemanfaatan Hasil Hutan Kayu (RKUPHHK) pada hutan alam unit manajemen PT SLJ II tahun 2006 dinyatakan bahwa untuk Desa Mahak Baru dan Dumu Mahak tanah ulen sudah dilakukan diidentifikasi awal namun pihak desa belum dapat menunjukkan lokasi yang pasti. Sementara pada dua desa lainnya yaitu Desa Long Top dan Desa Agung Baru, untuk lokasi tanah ulen dan lokasi cadangan berladang pihak desa belum dapat menunjukkan lokasi yang pasti. Begitu juga untuk Desa Data Baru, sebagai desa persiapan, penetapan tanah ulen dan lokasi cadangan belum dilakukan.

Perkembangan situasi pada saat dilakukan pengamatan, menurut informasi dari unit manajemen, tanah ulen untuk Desa Mahak Baru dan Dumu Mahak telah ditetapkan lokasinya dan saat ini sedang dalam proses tatabatas. Tanah adat Desa Long Top berada di luar area konsesi unit manajemen, pada tahun 2008 ini desa ini akan pindah ke Muara Sungai Uhu. Untuk Desa Agung Baru lokasi tanah ulen sudah ditetapkan dimana hal ini terkait RKT 2009, sedangkan untuk Desa Mahak lokasi tanah ulen sudah ditetapkan dimana hal ini terkait dengan RKT 2010 dan seterusnya.

\section{Terjaminnya cara perolehan hak}

Dalam rangka mewujudkan keterjaminan akses dan kontrol penuh masyarakat secara lintas generasi terhadap kawasan hutan adat, unit manajemen PT SLJ II telah melakukan penatatabatasan kawasan yang berkaitan dengan kawasan masyarakat desa sekitarnya secara partisipatif. Unit manajemen telah memiliki Peta Kawasan Lindung dan Partisipatif Desa di Areal PT SLJ II di Kecamatan Sungai Boh, Kabupaten Malinau (2006).

Pada tanggal 24 Januari 2006 pihak PT SLJ II telah melakukan kesepakatan dengan enam Kepala Desa di kawasan konsesi, para Kepala Adat, Tokoh Pemuda, dan diketahui Camat dan Polisi Sungai Boh. Pada saat itu disetujui tujuh butir kesepakatan oleh pihak-pihak yang ikut menandatangani kesepakatan tersebut. Selanjutnya berkenaan dengan adanya tuntutan warga masyarakat Mahak Baru pada tanggal 25 Nopember 2007 (sebanyak 15 item), maka pada tanggal 17 Januari 2008 
telah dilakukan kesepakatan antara masyarakat Kecamatan Sungai Boh dengan PT SLJ II dengan butir-butir sebagai berikut:

1. Lokasi RKT 2009 yang menjadi tanah adat Desa Mahak akan dipindahkan di atas Agung Baru (sebelah utara blok RKT 2008). Lokasi RKT 2009 yang menjadi tanah adat Desa Mahak akan direncanakan menjadi RKT 2010 dan akan diberi batas di lapangan dan diukur bersama oleh pihak masyarakat dan Perusahaan, untuk mengetahui lokasi yang boleh dikerjakan dan yang tidak boleh dikerjakan perusahaan. Mengingat waktu untuk menyelesaikan aspek legal kehutanan maka waktu diberikan selama 3 bulan.

2. Untuk RKT 2008, wakil masyarakat yang hadir akan membantu menyelesaikan dengan Desa Data Baru sehingga perusahaan dapat segera bekerja di RKT 2008.

3. Perusahaan tidak akan melarang masyarakat dalam mencari gaharu, emas, berburu dan hasil hutan lainnya dalam areal PT SLJ II.

4. Fee untuk masyarakat naik menjadi Rp 9000 per M3 untuk semua jenis kayu yang diproduksi, berlaku sejak Januari 2008. Sedangkan untuk produksi RKT tahun 2007 tetap dibayar sesuai dengan SK Gubernur Kaltim tahun 2000 .

5. Perusahaan akan berkomitmen memenuhi permintaan masyarakat sebanyak 15 buah seperti yang tercantum dalam surat masyarakat secara bertahap. Waktu penyelesaiannya akan dibicarakan pada pertemuan selanjutnya di camp atau di Kecamatan Sungai Boh.

6. Program bina desa perusahaan akan membantu kepada program kemandirian masyarakat, seperti pembangunan pertanian agar masyarakat tidak tergantung kepada hasil bumi, tetapi bisa menghasilkan komoditas pertanian dan perkebunan (kakao, nenas, dan kopi).

7. Akan dibentuk semacam forum komunikasi atau badan pengelola yang akan menjembatani kepentingan masyarakat dan perusahaan.

Sebagai tindak lanjut dari kesepakatan tersebut, unit manajemen telah menunjuk tim atau petugas dan memberitahukan kepada Camat Sungai Boh melalui surat tertanggal 29 Januari 2008 tentang rencana kegiatan penandaan batas partisipatif Blok RKT 2009 (Agung Baru) dan RKT 2010 (Hulu Sungai Mahak) yang akan dilakukan sekitar bulan Februari sampai Maret 2008. Selain itu, dalam rangka pembangunan Main Camp SLJ II di Batang Lataq, Desa Mahak Baru; unit manajemen telah membuat berita acara tentang persetujuan lahan. Kesepakatan telah dilakukan pada tanggal 25 Nopember 2007 yang ditandatangani oleh Site Manager, pejabat Camat Sungai Boh, Kepala Adat Sungai Boh, dan Kepala Desa Mahak Baru. Direncanakan camp baru tersebut akan menempati lahan seluas 9,6 Ha.

Untuk menghargai dan menghormati terhadap hak masyarakat, PT SLJ II telah menyusun berbagai kesepakatan dan memorandum. Namun dokumen yang ada belum mengakomodir atau menjamin keseluruhan perolehan hak melalui pembukaan hutan, misalnya berkenaan dengan pemanfaatan gaharu, ulin, emas, burung dan satwa lain yang perlu dilindungi. Berkaitan dengan akses dan kontrol penuh 
masyarakat secara lintas generasi terhadap kawasan hutan adat, unit manajemen belum melakukan monitoring secara rutin dan melibatkan seluruh perwakilan warga dan tokoh masyarakat secara lintas generasi, sehingga benar-benar mencerminkan keterjaminan cara perolehan hak melalui pembukaan hutan.

\section{Akses pemanfaatan hasil hutan oleh komunitas Mobilitas penduduk untuk pemanfaatan hasil hutan}

Mobilitas penduduk keluar-masuk kawasan konsesi untuk pemanfaatan hasil hutan belum terdata secara pasti, namun kepada setiap penduduk yang akan berdagang, mengambil gaharu, berobat, atau bepergian harus memperoleh surat keterangan jalan dari pihak keamanan unit manajemen. Tidak ada larangan unit manajemen terhadap komunitas untuk memanfaatkan hasil hutan non kayu. Jika suatu blok tebangan akan dikerjakan, PT SLJ II akan menginformasikan kepada masyarakat terlebih dahulu sehingga masyarakat dapat mengakses hasil hutan non kayu seoptimal mungkin. Hal ini dapat dilihat dari surat PT SLJ II ke desa-desa di Kecamatan Sungai Boh tentang pemberian peluang/kesempatan kepada seluruh masyarakat di sekitar HPH untuk memanfaatkan berbagai jenis HHNK seperti gaharu, rotan, sarang burung wallet, madu, dan lain-lain. Mobilitas masyarakat terhadap pemanfaatan hasil hutan non kayu tergantung pada saat musim buah. Komunitas juga tidak memanfaatkan hasil hutan rotan disebabkan karena harga pasaran rotan yang tidak menguntungkan.

Hasil hutan non kayu (HHNK) yang memiliki nilai ekonomis bagi masyarakat adalah gaharu, emas, dan buah durian. HHNK lainnya (seperti madu, rotan, binatang buruan) biasanya untuk konsumsi sendiri dan tidak dikomersilkan. Sehubungan dengan pemanfaatan gaharu dan penambangan emas yang dilakukan masyarakat Desa Mahak Baru dan Desa Dumu Mahak, pihak pemerintahan desa dan pemangku adat setempat mengeluarkan Peraturan Desa No. 002 tahun 2005, Peraturan Hukum Adat No. 16 tahun 2003 dan Surat Edaran Kepala Adat Besar No. 05/10.4/KAB-KSB/2004, yang mengatur tentang pemanfaatan hasil hutan desa dan hasil tambang desa.

\section{Pemanfaatan hasil hutan non kayu}

Pengetahuan unit manajemen tentang hasil hutan non kayu cukup baik. Unit manajemen sudah melakukan inventarisasi hasil hutan non kayu, memplotkan peta penyebarannya (mengetahui penyebaran ekosistemnya, contoh : Peta Sebaran Pohon Poligon Blok No. 1529 dan 1531), memprediksi jumlah potensi yang ada dan menginformasikan hasil hutan non kayu tersebut terhadap komunitas, namun masih terbatas pada beberapa HHNK, antara lain ulin, banggeris dan sarang burung.

PT Sumalindo Lestari Jaya II telah menyelesaikan survei Participatory Conservation Plan (PCP) pada semua desa di dalam kawasan hutannya. Survei PCP tersebut di antaranya bertujuan untuk mengetahui derajat kepentingan masyarakat terhadap hasil hutan kayu dan hasil hutan non kayu. Seperti diketahui bahwa untuk HHNK yang paling banyak dicari/dimanfaatkan oleh masyarakat adalah gaharu. Mengantisipasi kelangkaan akan gaharu di kemudian hari PT SLJ II selain mendukung peraturan kampung mengenai pembatasan orang luar untuk mencari gaharu juga dengan memanfaatkan keunggulan teknologi persemaian (pembiakan 
vegetatif) untuk pengadaan bibit gaharu bagi masyarakat dan rencana pembuatan demplot kebun gaharu.

Dalam rangka pemanfaatan hasil hutan non kayu, unit manajemen belum sepenuhnya melakukan kegiatan pengelolaan pada areal kawasan komunitas (tanah ulen, areal perburuan, areal tegakan ulin, dll) meliputi kegiatan inventarisasi, identifikasi, penanaman, pemeliharaan, dan pemantauan. Selanjutnya unit manajemen diharapkan dapat menginformasikan hasil pengelolaan kawasan komunitas tersebut kepada masyarakat setempat.

\section{Peraturan perihal mobilitas penduduk}

Unit manajemen tidak pernah melarang penduduk keluar-masuk kawasan konsesi, kecuali untuk berladang di areal efektif. Areal HPH yang berupa main road berfungsi sebagai jalan penghubung masyarakat dari desa-desa Kecamatan Sungai Boh dengan Long Bagun (KM-0) sebagai pusat pertumbuhan terdekat. Mobilitas penggunaan main road dilakukan dua (2) kali seminggu yaitu pada tanggal 15 dan 30 setiap bulannya dengan memberikan fasilitas angkutan sebanyak 2 unit (daya tampung 80 orang) setiap ada mobilisasi.

Unit manajemen melarang pendatang (termasuk karyawan PT SLJ II) melakukan pemungutan hasil hutan non kayu khususnya gaharu di dalam areal PT SLJ II dengan cara melakukan pemeriksaan orang-orang yang keluar-masuk areal. Hal ini atas permintaan masyarakat adat Kecamatan Sungai Boh (Keputusan Lembaga Adat sedaerah Sungai Boh di Lebusan tentang larangan mencari gaharu bagi orang luar di daerah Sungai Boh dan Apau Kayan mulai tanggal 1 Juni 2001). Apabila pendatang melakukan pemungutan hasil hutan non kayu (gaharu) di areal PT SLJ II, terlebih dahulu harus minta ijin dari kepala adat setempat dengan memperhatikan dan mentaati peraturan adat yang ada. Kontribusi unit manajemen dalam hal ini adalah (i) memeriksa pendatang yang keluar masuk areal khususnya pencari gaharu, dan (ii) mensosialisasikan Keputusan Lembaga Adat sedaerah Sungai Boh terhadap seluruh pekerja PT SLJ II dengan menempelkan papan pengumuman di masingmasing camp unit. Unit manajemen membantu masyarakat di dalam hal pengangkutan hasil hutan kayu (HHK) untuk keperluan fasilitas desa dan hasil hutan non kayu (HHNK).

Dalam Memorandum Site Manager Long Bangun No. 069/SLJII/LB/SH/PERS/VIII/2005 tanggal 10 Agustus 2005 dinyatakan anjuran kepada setiap karyawan bahwa dalam melakukan pekerjaan sehari-hari senantiasa melaksanakan prinsip saling menghormati dan menghargai terutama dalam : (1) setiap penggunaan pengetahuan tradisional dalam menunjang pekerjaan di perusahaan, maka wajib memberikan kompensasi kepada tenaga kerja yang digunakan di luar upah reguler; (2) setiap karyawan wajib menghormati dan menghargai budaya dan adat istiadat setempat baik dalam hubungan sosial kemasyarakatan maupun hal-hal lainnya yang dianggap menunjang adat atau budaya setempat; dan (3) mewajibkan kepada setiap karyawan yang mengetahui/menemukan peninggalan adat/budaya (situs budaya) setempat kepada supervisor masing-masing, untuk selanjutnya diambil tindakan perlindungan terhadap situs tersebut. 
Sebelum perusahaan melaksanakan kegiatan operasional diharapkan masyarakat untuk mencari atau mengambil hasil hutan non kayu berupa gaharu, damar, rotan, dll. Hal ini selalu dilakukan setiap kali akan melakukan RKT, seperti terakhir kali ketika unit manajemen memberitahukan lokasi RKT 2008 kepada Camat dan seluruh Kepala Desa di Kecamatan Sungai Boh melalui surat No. 03/SM/SLJ-II/LB/I/08 tanggal 03 Januari 2008. Informasi tersebut selanjutnya akan diberitahukan kepada warga masyarakat.

Pada tanggal 24 Januari 2006 pihak PT SLJ II telah melakukan kesepakatan dengan enam Kepala Desa di kawasan konsesi, para Kepala Adat, Tokoh Pemuda, dan diketahui Camat dan Polisi Sungai Boh. Terdapat tujuh butir kesepakatan yang disetujui oleh pihak-pihak yang ikut menandatangani kesepakatan tersebut, di antaranya adalah kesepakatan tentang :

- PT SLJ II boleh melakukan pengelolaan/beroperasi di daerah Lalut Emas dan masyarakat dihimbau untuk tidak melakukan pengambilan (mendulang) emas ketika perusahaan beroperasi di daerah tersebut;

- untuk pengambilan kayu bagi keperluan sendiri, masyarakat harus menggayat di dalam lokasi kemudian mereka membawa sendiri hasilnya ke tepi jalan, dan selanjutnya akan dibantu pihak perusahaan untuk mengangkutnya;

- perlu dibentuk wakil-wakil masyarakat yang menjembatani permasalahan yang timbul antara masyarakat dengan perusahaan

- dalam kawasan valet blaka (1000 meter kiri-kanan jalan) perusahaan tidak boleh mengambil kayu marsolok, ulin dan arau

- pihak perusahaan akan memfasilitasi pihak kecamatan Sungai Boh bertemu dengan Gubernur dan Wakil Gubernur Kalimantan Timur dalam rangka membahas penambahan fee produksi dari kayu blok RKT.

Dalam rangka menindaklanjuti memorandum-memorandum sebelumnya, pada tanggal 13 Januari 2007 Site Manager PT SLJ II telah mengeluarkan Memorandum yang bersifat mengatur ketertiban dan keamanan lingkungan unit manajemen, khususnya bagi para karyawan dan warga komunitas sekitar. Memorandummemorandum tersebut tampaknya masih cukup efektif diperhatikan oleh para karyawan.

\section{Sumber-sumber ekonomi komunitas}

\section{a. Tidak ada kerawanan pangan}

Sebagai konsekuensi dari dilakukannya kegiatan operasional, pihak perusahaan melaksanakan program Pembinaan Masyarakat Desa Hutan (PMDH) untuk mengelola dampak akibat kegiatan operasional terhadap lingkungan sosial. Salah satu dampak yang mungkin timbul adalah kerawanan pangan akibat rusak dan hilangnya sumber-sumber ekonomi komunitas, yang merupakan sumber mata pencaharian masyarakat setempat sesuai tipologi perusahaan menurut aspek sosial.

Berdasarkan dokumen RKT 2008, unit manajemen merencanakan program PMDH dengan melaksanakan kegiatan-kegiatan pembinaan masyarakat meliputi : (1) 
Kegiatan peningkatan pendapatan, tumbuhnya ekonomi masyarakat pedesaan yang berwawasan lingkungan, (2) Kegiatan penyediaan sarana dan prasarana sosial ekonomi, dan (3) Kegiatan penciptaan kesadaran dan perilaku positif dalam pelestarian SDA. Alokasi biaya yang direncanakan untuk kegiatan PMDH RKT 2007 pada kelima desa di dalam kawasan konsesi sebesar Rp. 443.850.000,00 dan terealisasi sebesar Rp. 649.877.000,00 (146\%). Adapun rencana anggaran kegiatan PMDH untuk tahun 2008 sesuai dengan dokumen RKT 2008 adalah sebesar Rp 430.200.000,00.

Selain kegiatan $\mathrm{PMDH}$, unit manajemen melaksanakan kegiatan penataan batas bersama-sama maupun partisipatif pada areal hutan yang menjadi sumber-sumber ekonomi masyarakat setempat, yaitu : tanah ulen, areal pemanfaatan ulin, areal berburu, areal pemanfaatan HHNK (rotan), dan lain-lain. Penataan batas dilakukan untuk menghindari terjadinya kerusakan terhadap sumber-sumber ekonomi masyarakat yang secara lintas generasi dimanfaatkan sebagai sumber mata pencaharian penduduk setempat. Berdasarkan Peta Kerja untuk RKT 2008, areal kerja unit manajemen untuk kegiatan penebangan berdekatan dengan batas kawasan komunitas Desa Agung Baru dan Data Baru.

Pada saat kegiatan dilakukan pengamatan, warga masyarakat sedang disibukkan dengan kegiatan panen padi ladang. Hasil produksi padi ladang saat ini cukup bagus sehingga diperkirakan akan mampu mencukupi kebutuhan pangan bagi warga desa setempat. Hasil wawancara dengan masyarakat dan petugas Puskesmas setempat menyebutkan bahwa kerawanan pangan tidak pernah terjadi sebagai akibat kegiatan operasional unit manajemen.

\section{b. Kompensasi yang adil dan wajar}

Di wilayah Kalimantan Timur terdapat Keputusan Gubernur No. 20 Tahun 2000 tentang Penetapan Dana Kompensasi Kepada Masyarakat di Dalam dan Sekitar Hutan di Propinsi Kalimantan Timur. SK Gubernur tersebut menetapkan bahwa perusahaan pemegang izin pemanfaatan hasil hutan kayu membayar kompensasi sesuai jenis yang dimanfaatkan (untuk kelompok meranti dikenakan sebesar Rp 3.000,00 per m3 dan kelompok rimba campuran sebesar Rp 2.000,00 per m3). Semenjak dikeluarkannya keputusan tersebut, pihak unit manajemen memberikan dana kompensasi berdasarkan realisasi produksi setiap tahun RKT. Sampai dengan tahun 2007, pemberian dana kompensasi kepada masyarakat melalui Camat diserahkan dalam bentuk uang tunai.

Untuk tahun 2005 PT SLJ II menetapkan dana kompensasi masyarakat sebesar Rp 341.636.560,00 yang didasarkan pada realisasi produksi RKT 2005 sebesar 114.694,54 m3, yang terdiri dari kelompok Meranti $=112.247,48 \mathrm{~m} 3(\mathrm{Rp}$ 336.742.440,00) dan kelompok campuran $=2.447,06 \mathrm{~m} 3(\operatorname{Rp} 4.894 .120,00)$. Sementara itu untuk tahun 2006 pada semester I PT SLJ II menetapkan dana kompensasi masyarakat sebesar Rp 99.983.140,00 yang didasarkan pada realisasi produksi RKT 2006 sebesar 34.075,80 m3, yang terdiri dari kelompok Meranti = $31.831,54 \mathrm{~m} 3(\mathrm{Rp} 95.494 .620,00)$ dan kelompok campuran $=2.244,26 \mathrm{~m} 3(\mathrm{Rp}$ 4.488.520,00). Grand total kewajiban PT SLJ II sampai bulan Juni 2006 sebesar Rp 498.380.150,00; sedangkan pengambilan advance dana kompensasi (fee) sebanyak Rp 314.505.310,00 sehingga sisa kewajiban PT SLJ II adalah sebesar Rp 183.874.840,00. Dana sejumlah itu sudah dibayarkan kepada Camat Sungai Boh 
pada tanggal 4 Januari 2007. Sementara itu, untuk pembayaran dana kompensasi/fee bulan Juli-Desember 2006 sebesar Rp 177.847.180,00 telah dibayarkan pada tanggal 3 Maret 2007. Selanjutnya untuk tahun 2007 pada semester I PT SLJ II menetapkan dana kompensasi masyarakat sebesar Rp 106.844.700,00 yang terdiri dari kelompok meranti/kayu indah $=34.833,74 \mathrm{~m} 3(\mathrm{Rp} 104.501 .220,00)$ dan kelompok rimba campuran $=1.171,74 \mathrm{~m} 3(\operatorname{Rp} 2.343 .480,00)$. Dana sejumlah itu sudah dibayarkan kepada Camat Sungai Boh pada tanggal 21 Januari 2008.

\section{c. Nilai hasil hutan non kayu}

Hasil hutan non kayu (HHNK) yang memiliki nilai ekonomis bagi masyarakat adalah gaharu, emas, buah durian. HHNK lainnya (seperti : madu, rotan, binatang buruan) biasanya untuk konsumsi sendiri dan tidak dikomersilkan. Sehubungan dengan pemanfaatan gaharu dan penambangan emas yang dilakukan masyarakat Desa Mahak Baru dan Desa Dumu Mahak, pihak pemerintahan desa dan pemangku adat setempat mengeluarkan Peraturan Desa No. 002 tahun 2005, Peraturan Hukum Adat No. 16 tahun 2003 dan Surat Edaran Kepala Adat Besar No. 05/10.4/KAB$\mathrm{KSB} / 2004$, yang mengatur tentang pemanfaatan hasil hutan desa dan hasil tambang desa.

Untuk mengetahui pendapatan masyarakat dari hasil pemanfaatan HHNK tidak ada data yang tersedia. Namun, menurut informasi lisan dari hasil wawancara dengan masyarakat, diperoleh informasi bahwa untuk pendapatan dari pengambilan gaharu sudah berkurang karena sekarang ini gaharu sudah sulit ditemukan. Unit manajemen mencoba memperkirakan data hasil pengumpulan gaharu dan penambangan emas oleh masyarakat pada tahun 2007. Untuk gaharu diperkirakan jumlah pengumpul ada 17 orang dengan total nilai Rp 9.520.000.000,00 sedangkan untuk emas jumlah pengumpul sebanyak 10 orang dengan total nilai diperkirakan sebesar Rp $180.000 .000,00$.

\section{d. Pemanfaatan hasil hutan kayu}

Dalam pemetaan partisipatif, disepakati bahwa pemanfaatan HHK untuk kebutuhan masyarakat dapat diambil dari hutan yang berada dalam batas kawasan yang telah ditentukan batasnya secara bersama (collaborative). Sejauh ini masyarakat tidak mengalami kesulitan dalam hal pemanfaatan hasil hutan kayu untuk kebutuhan komunitas, baik untuk bangunan rumah warga, fasilitas umum maupun pemerintahan. Kemudahan ini disebabkan adanya pembukaan jalan menuju pemukiman warga dimana PT SLJ II terlibat dalam kegiatan pembukaan jalannya.

\section{e. Peningkatan nilai tambah hasil hutan}

Kecuali gaharu dan emas, komunitas masyarakat Kecamatan Sungai Boh jarang memanfaatkan hasil hutan non kayu untuk tujuan komersial dan untuk mengetahui seberapa besar peningkatan HHNK dan HHK yang dimanfaatkan tidak tersedia data yang akurat. Pendekatan yang dapat digunakan untuk mengetahui peningkatan nilai tambah HHK dan HHNK adalah dengan melihat dari sisi pembangunan perumahan warga desa, perkembangan berbagai fasilitas umum, dan bertambahnya usaha yang berkembang di lokasi tersebut; dimana pada saat penilikan dilakukan terjadi peningkatan cukup signifikan, khususnya untuk masyarakat Desa Mahak Baru dan Dumu Mahak. 
Berdasarkan hasil pengamatan di lapangan menunjukkan bahwa perkembangan sarana fisik terutama di Desa Mahak Baru dan Dumu Mahak dalam setahun terakhir cukup meningkat. Selain terdapat fasilitas Kantor Camat Sungai Boh, pada tahun 2007 telah dibangun antara lain Balai Pertemuan Umum (BPU), bangunan sekolah untuk SMP, rumah dinas dokter, rumah penginapan, dan tower Telkomsel yang sangat memperlancar komunikasi di sekitar kawasan. Selain itu, sarana transportasi warga lebih terbantu dengan adanya motor dan angkutan pedesaaan. Pada saat ini jumlah pemilik sepeda motor di kedua desa itu cukup meningkat dibanding tahun sebelumnya. Diperkirakan pada saat ini jumlah motor di kedua desa itu lebih dari 100 buah. Dalam pemanfaatannya sebagai sarana transportasi, telah dibuat kesepakatan agar digunakan hanya di sekitar kawasan desa sehingga tidak mengganggu kegiatan operasional kendaraan milik unit manajemen di lokasi kawasan hutan.

\section{f. Ragam olahan hasil hutan non kayu dan kayu}

Tidak ditemukan adanya industri rumahtangga (home industri) yang menggunakan hasil hutan non kayu dan kayu sebagai bahan baku untuk kegiatan industri kehutanan maupun industri pengolahan lainnya. Untuk gaharu dan emas yang diambil oleh masyarakat setempat dijual langsung tanpa dilakukan proses pengolahan lebih lanjut. Sedangkan kayu hanya digunakan untuk keperluan material dan perabotan rumah. Pada saat penilikan lapangan dilakukan, peningkatan ragam olahan HHNK dan HHK tidak mengalami perubahan yang berarti, jika dibandingkan dengan kegiatan penilikan yang sebelumnya.

\section{Akses kesempatan kerja dan peluang berusaha Warga komunitas yang diutamakan bekerja}

Berdasarkan Daftar Karyawan PT SLJ II - Site Long Bagun Bulan Februari 2008, diperoleh data mengenai jumlah tenaga kerja sebanyak 369 orang. Dari jumlah tersebut, tenaga kerja lokal yang berasal dari wilayah Kalimantan Timur sebanyak 140 orang $(37,94 \%)$ dan yang berasal dari luar Kalimantan Timur sebanyak 229 orang $(62,06 \%)$. Selain memperkerjakan tenaga kerja tetap, unit manajemen juga memanfaatkan tenaga kerja lokal yang berasal dari dalam kawasan konsesi (Kecamatan Sungai Boh) yang bekerja di perusahaan sebagai tenaga harian lepas sebanyak 40 orang. Untuk memenuhi kebutuhan tenaga kerja yang diperlukan setiap tahunnya, unit manajemen membuat rencana kebutuhan tenaga kerja yang dituangkan dalam dokumen Man Power Planning, dan untuk tahun 2008 perusahaan telah membuat rencana tersebut.

\section{Kesempatan kerja tidak diskriminatif}

Dalam hal lowongan tenaga kerja, pihak perusahaan menyampaikan surat permintaan tenaga kerja kepada Camat Sungai Boh dan seluruh Kepala Desa di Kecamatan Boh. Permintaan tenaga kerja biasanya untuk menduduki jabatan operator felling, operator skidding, timber marker, dan tenaga survey.

Hasil wawancara dengan tokoh masyarakat di Desa Long Lebusan, Mahak Baru dan Dumu Mahak serta staf Kecamatan Sungai Boh diperoleh keterangan bahwa unit manajemen telah beberapa kali memberikan informasi atau pemberitahuan tertulis tentang adanya lowongan pekerjaan di perusahaan. Surat tersebut ditujukan kepada Camat dan Kepala Desa terutama untuk permintaan tenaga kerja dalam rangka 
kegiatan survey di lapangan. Surat penawaran kerja ini selanjutnya disampaikan oleh Kepala Desa kepada masyarakat di sela-sela pertemuan desa, aktivitas keagamaan, dan lain-lain.

\section{Penyerapan tenaga kerja lokal}

Berdasarkan laporan tenaga kerja Bulan Februari 2008 dan promosi peningkatan karier karyawan tahun 2007 diperoleh data tenaga kerja lokal yang berasal dari kecamatan Sungai Boh umumnya menduduki jabatan sebagai operator felling, timber marker dan skidding. Terdapat 11 orang tenaga kerja lokal dari wilayah Kalimantan Timur yang menduduki jabatan staf tetap non pelaksana, seperti Koordinator Reg. Long Bangun, Supervisor Log Processing, Asisten Forest Plan, Kasie Ware House, Kasie FOL, Kasie Road Maintenance, Staff Produksi, Kasir, dan sebagainya.

Menurut hasil wawancara, diperoleh informasi bahwa sedikitnya tenaga kerja lokal yang berasal dari Sungai Boh yang menjadi staf tetap, dikarenakan beberapa faktor yang berpengaruh, antara lain: (1) Rendahnya tingkat pendidikan masyarakat, (2) Penghasilan dari hasil gaharu dan emas lebih besar dibanding bekerja di perusahaan, dan (3) Masyarakat cenderung lebih suka bekerja hanya pada saat-saat tertentu saja dan tidak terikat dengan aturan waktu kerja yang ditetapkan oleh perusahaan. Dengan demikian masyarakat dapat melakukan pekerjaan lain di luar pekerjaan yang disepakati, misal mencari gaharu, emas, berburu dan lain-lain.

\section{Pengembangan usaha baru}

Dengan diperbaikinya jalan kecamatan Sungai Boh, berpengaruh signifikan terhadap peningkatan usaha baru yang dikembangkan warga komunitas. Usaha yang berkembang adalah bengkel motor, toko sparepart, koperasi, warung, wartel, usaha pertanian (sayuran dan buah-buahan). Berdasarkan data monografi desa tahun 2007 yang disusun oleh PT SLJ II, diperoleh data jumlah usaha warga desa seperti yang disajikan pada tabel berikut.

Tabel 1. Jumlah Usaha Warga Desa Kecamatan Sungai Boh Tahun 2007

\begin{tabular}{|c|l|c|c|c|}
\hline No. & \multicolumn{1}{|c|}{ Nama Desa } & $\begin{array}{c}\text { Kios/Toko } \\
\text { Kelontong }\end{array}$ & Gilingan Padi & $\begin{array}{c}\text { Usaha Lain } \\
\text { (Koperasi, wartel, penjahit, } \\
\text { bengkel, dll) }\end{array}$ \\
\hline 1. & Dumu Mahak & 18 & 1 & 5 \\
\hline 2. & Mahak Baru & 17 & 4 & 7 \\
\hline 3. & Long Lebusan & 15 & 3 & - \\
\hline 4. & Agung Baru & 8 & 2 & 2 \\
\hline 5. & Long Top & 2 & 1 & - \\
\hline 6. & Data Baru & 9 & 2 & - \\
\hline
\end{tabular}

Sumber : Data Monografi Desa di dalam Areal HPH PT SLJ II Tahun 2008

Pada tabel tersebut terlihat bahwa Desa Mahak Baru dan Desa Dumu Mahak mempunyai jumlah usaha cukup banyak dibanding desa-desa lainnya. Salah satu faktor yang berpengaruh disebabkan akses jalan dari desa ke pusat pembelajaan lebih mudah dibandingkan desa lainnya. 


\section{Besaran dan distribusi belanja unit manajemen dalam wilayah lokal}

Belanja UM dalam wilayah lokal terbatas pada hasil sayuran dan ayam yang dipasok dari penduduk binaan di Kecamatan Sungai Boh dan Desa Batu Majang. Besaran belanja UM yang telah dikeluarkan selama tiga tahun terakhir disajikan pada tabel berikut.

Tabel 2. Besaran Belanja PT. Sumalindo Lestari Jaya Unit II dalam Wilayah Lokal selama Tiga Tahun Terakhir (2005-2007)

\begin{tabular}{|c|c|c|}
\hline No. & Tahun & Jumlah (Rp) \\
\hline 1. & 2005 & $166.507 .875,00$ \\
\hline 2. & 2006 & $179.763 .640,00$ \\
\hline 3. & 2007 & $177.701 .705,00$ \\
\hline \multicolumn{2}{|c|}{ Total } & $523.973 .220,00$ \\
\hline & Rata-rata & $174.657 .740,00$ \\
\hline
\end{tabular}

Berdasarkan tabel di atas dapat dilihat bahwa rata-rata belanja UM dalam wilayah lokal per tahun dalam tiga tahun terakhir sebesar Rp 174.657.740,00. Nilai ini lebih besar dari tahun 2006 yang memiliki nilai rata-rata sebesar Rp 149.860.316,00. Namun pada tahun 2007 terjadi penurunan belanja lokal sebesar Rp 2.610.935,00 dibandingkan tahun 2006.

\section{Terjaminnya hak asasi manusia Rendahnya kasus tindak kekerasan terhadap warga oleh unit manajemen atau aparat}

Tidak ditemukan adanya kasus tindak kekerasan terhadap warga oleh unit manajemen atau pihak aparat. Dalam Memorandum Site Manager Long Bangun No. 069/SLJ-II/LB/SH/PERS/VIII/2005 tanggal 10 Agustus 2005 dinyatakan anjuran kepada setiap karyawan bahwa dalam melakukan pekerjaan sehari-hari senantiasa melaksanakan prinsip saling menghormati dan menghargai terutama dalam : (1) setiap penggunaan pengetahuan tradisional dalam menunjang pekerjaan di perusahaan, maka wajib memberikan kompensasi kepada tenaga kerja yang digunakan di luar upah reguler; (2) setiap karyawan wajib menghormati dan menghargai budaya dan adat istiadat setempat baik dalam hubungan sosial kemasyarakatan maupun hal-hal lainnya yang dianggap menunjang adat atau budaya setempat; dan (3) mewajibkan kepada setiap karyawan yang mengetahui/menemukan peninggalan adat/budaya (situs budaya) setempat kepada supervisor masing-masing, untuk selanjutnya diambil tindakan perlindungan terhadap situs tersebut.

Dalam rangka menindaklanjuti memorandum-memorandum sebelumnya, pada tanggal 13 Januari 2007 Site Manager unit manajemen PT SLJ II telah mengeluarkan Memorandum yang bersifat mengatur ketertiban dan keamanan lingkungan unit manajemen, khususnya bagi para karyawan dan warga komunitas sekitar. Memorandum-memorandum tersebut tampaknya cukup efektif diperhatikan oleh para karyawan sehingga, sejauh ini tidak terjadi pelaporan adanya klaim oleh warga tentang kasus pelanggaran HAM dan tindak kekerasan oleh karyawan maupun pihak aparat keamanan. 


\section{Kebebasan berserikat bagi buruh}

Pekerja tidak pernah dihalang-halangi untuk masuk menjadi anggota serikat pekerja. Di perusahaan ini telah terbentuk organisasi serikat pekerja yang bernama Serikat Pekerja Kahutindo yang berdiri sejak 17 April 2004 dengan jumlah anggota saat ini sebanyak 369 orang.

Hasil wawancara dengan pengurus serikat pekerja diperoleh informasi, bahwa untuk tahun 2007 beberapa masalah perburuhan yang terjadi semuanya telah diselesaikan dengan baik. Hal ini didukung dengan adanya Klinik Ketenagakerjaan yang dibentuk dalam rangka memberikan arahan dan konsultasi bagi para karyawan yang menghadapi masalah dengan pekerjaannya.

\section{Kerja sama dengan otoritas kesehatan Ragam dan kualitas pelayanan kesehatan}

Sejak berdirinya Puskesmas Kecamatan Sungai Boh, masyarakat menjadi lebih mudah memperoleh pelayanan kesehatan secara gratis (bagi masyarakat yang mempunyai kartu Gaskin) dan relatif murah (bagi masyarakat yang tidak mempunyai kartu Gaskin). Ragam dan kualitas pelayanan Puskesmas cukup banyak dan beragam dengan tim medis terdiri dari dokter umum, bidan dan para mantri. Dengan berdirinya Puskesmas tersebut berpengaruh terhadap jumlah kunjungan masyarakat ke poliklinik unit manajemen, dimana pada tahun 2007 jumlah kunjungan masyarakat ke poliklinik mengalami penurunan, yakni hanya sejumlah 164 orang. Total pasien di poliklinik pada tahun 2007 adalah sebanyak 2.753 orang, terutama untuk lima jenis penyakit utama yang diderita yaitu influenza 737 orang pasien, ISPA 687 orang pasien, penyakit kulit 361 orang pasien, penyakit lambung gastritis 291 orang pasien, dan rematik 237 orang pasien. Sementara itu berkenaan dengan biaya pengobatan, data dari Poliklinik PT SLJ II menunjukkan bahwa biaya pengobatan karyawan pada tahun 2007 sebanyak Rp 46.392.745,00. Sementara itu biaya pengobatan untuk keluarga karyawan pada tahun 2007 di lokasi unit manajemen sebesar Rp 35.841.851,00 dengan total jumlah pasien 1554 orang.

Terhitung mulai tanggal 22 Februari 2008 diberlakukan plafon biaya kamar rumah sakit (rawat inap) dan penggantian biaya pengobatan yang baru. Untuk layanan rawat inap bekerjasama dengan rumah sakit Dirgahayu untuk wilayah Kalimantan Timur dan dengan rumah sakit Sumber Waras DKI Jakarta untuk wilayah luar Kalimantan Timur.

\section{Upaya meningkatkan kesadaran komunitas dan karyawan}

Dengan adanya Puskesmas baru, unit manajemen tidak lagi melakukan kunjungan rutin namun dukungan untuk upaya peningkatan kesadaran masyarakat terhadap penyakit tetap konsisten. Hal ini dibuktikan pada saat penilikan dilakukan, unit manajemen membantu dalam transportasi dari Puskesmas menuju $\mathrm{km} 0$ bagi pasien yang tidak dapat ditangani oleh Puskesmas dan membutuhkan penanganan lebih lanjut. Selain itu, dukungan lainnya adalah adanya bantuan sumbangan fisik berupa tempat tidur pasien, meja, dan lain-lain untuk Puskesmas. 
Unit manajemen giat melakukan sosialisasi kepada masyarakat dan karyawan khususnya menyangkut penggunaan jalan utama perusahaan dalam kaitan mencegah terjadinya kecelakaan lalulintas.

\section{KESIMPULAN DAN SARAN Kesimpulan}

Berdasarkan hasil analisis menunjukkan bahwa kinerja aspek sosial pengelolaan hutan lestari pada unit manajemen PT SLJ II memiliki kinerja yang cukup baik, namun disain dan upaya yang dilakukan oleh unit manajemen untuk mengimplementasikan program aspek sosial ternyata belum mencapai target sasaran yang diharapkan. Hal ini ditunjukkan oleh kinerja aspek sosial yang baik dari PT SLJ II tetapi kinerja tersebut tidak berhubungan dengan peningkatan kesejahteraan warga komunitas di sekitarnya.

Tidak ada klaim perusahaan tersebut terhadap wilayah masyarakat adat dan unit manajemen telah melakukan penatabatasan secara partisipatif di seluruh desa yang berada di sekitar kawasan konsesi. Berkaitan dengan akses dan kontrol penuh masyarakat secara lintas generasi terhadap kawasan hutan adat, unit manajemen belum mampu menjamin dan melibatkan seluruh perwakilan warga dan tokoh masyarakat secara lintas generasi. Unit manajemen secara konsisten melaksanakan program dan kesepakatan yang telah dibuat dengan masyarakat serta ada upayaupaya unit manajemen untuk meningkatkan akses komunitas pada kesempatan kerja dan peluang berusaha yang terbuka, namun belum berkontribusi secara nyata bagi peningkatan kesejahteraan warga komunitas.

\section{Saran}

Beberapa saran yang dapat diberikan untuk peningkatan kinerja aspek sosial PT SLJ II antara lain :

a. Berkaitan dengan akses dan kontrol penuh masyarakat terhadap kawasan hutan adat, unit manajemen perlu melakukan monitoring secara rutin dan melibatkan seluruh perwakilan warga atau tokoh masyarakat, sehingga benar-benar mencerminkan keterjaminan cara perolehan hak melalui pembukaan hutan secara lintas generasi.

b. Melakukan monitoring dan pendataan pengambilan hasil hutan kayu dan hasil hutan non kayu, serta melakukan monitoring terhadap ladang berpindah yang dilakukan oleh masyarakat.

c. Melakukan penyusunan Rencana Pembangunan Jangka Menengah Desa (RPJMD) untuk lima tahun ke depan dengan mengacu pada hasil kajian/survei sosial ekonomi yang telah dilakukan.

d. Melakukan rencana pengembangan sumber daya manusia dan pemberdayaan masyarakat bagi warga masyarakat sekitar untuk jangka panjang misalnya dengan merancang program beasiswa bagi pelajar putra daerah yang berprestasi untuk menekuni bidang-bidang profesi yang diperlukan dalam pengelolaan unit manajemen, sehingga mereka akan dapat bekerja di unit manajemen sesuai dengan profesi yang ditekuninya.

e. Meningkatkan program pelatihan untuk pemberdayaan SDM masyarakat lokal guna penciptaan peluang berusaha dan peningkatan penyerapan tenaga kerja lokal. Untuk itu unit manajemen perlu mengembangkan kapasitas personal 
tenaga community development yang bertugas di lapangan, sehingga dapat mendukung program tersebut secara optimal.

f. Meningkatkan kerjasama dengan otoritas kesehatan dalam rangka upaya peningkatan status gizi dan kesehatan masyarakat dan mengalokasikan sumberdaya yang cukup untuk kegiatan promosi gizi dan kesehatan.

\section{DAFTAR PUSTAKA}

Data Monografi Desa di dalam Areal HPH PT. SLJ II Tahun 2008.

Laporan Bagian Personalia PT. SLJ II Tahun 2007.

Laporan Kegiatan Pelatihan Karyawan PT. SLJ II Tahun 2007.

Laporan Monitoring Kasus dan Penyelesaiannya PT. SLJ II Tahun 2007.

Laporan Pemanfaatan Hasil Hutan Non Kayu PT. SLJ II Tahun 2007.

Laporan Pembinaan Masyarakat Desa Hutan (PMDH) PT. SLJ II Tahun 2006-2007.

Lembaga Ekolabel Indonesia. Sistem Sertifikasi Pengelolaan Hutan Produksi Lestari. Bogor: LEI, 2000.

Memorandum Site Manager Long Bangun No. 069/SLJ-II/LB/SH/PERS/ VIII/2005 tanggal 10 Agustus 2005 tentang Anjuran Kepada Setiap Karyawan PT. SLJ II.

Rencana Kerja Usaha Pemanfaatan Hasil Hutan Kayu PT. SLJ II Tahun 2007-2016.

Surat Edaran Kepala Adat Besar No. 05/10.4/KAB-KSB/2004 tentang Pemanfaatan Hasil Hutan Desa dan Hasil Tambang Desa.

Surat Keputusan Gubernur Kalimantan Timur No. 561/K.532/2006 tanggal 14 Desember 2006 tentang Penetapan Upah Minimum Sektoral Provinsi (UMSP) Sektor Perkayuan dan Kehutanan Kalimantan Timur Tahun 2007. 
